\title{
SELECTION OF ADVERTISING APPEALS IN SLOVAK TELEVISION ADVERTISING
}

\author{
Zuzana Ihnátová
}

\begin{abstract}
Purpose of the article The issue of creating advertising that is culturally congruent has been considered to be very important to experts dedicated to the field in the past years. Culture is an important internal factor of customer behavior that needs to be fully considered if the advertising campaigns aim to address its target audience effectively. The goal of this article is to contribute to existing knowledge in the area of culturally congruent advertising. More specifically, to find out what advertising appeals are preferred in Slovak television advertising. Methodology/methods Main scientific method of the present research was conceptual content analysis. The results are based on the sample of $133 \mathrm{TV}$ commercials broadcasted in Slovak televisions during the 2012 in selected four segments (beer, financial services, periodicals and non-alcoholic beverages). Scientific aim Aim of this contribution is the introduction of preferences and frequency of usage of advertising appeals used in Slovak television advertising. Subsequenty, the exploration of the links between the selection of advertising appeals and cultural dimensions of Slovaks are analyzed. Findings The largest representation in analyzed television commercials in all examined segments has the appeal to relaxation.), followed by the appeal of suitable, then the appeal of saving, the appeal to patriotism, the appeal of natural and the appeal to affiliation. In the surveyed segments the preferences of individual advertising appeals are somehow different and reflect existing influence of product category on creative strategy. The findings show the positive relation between selection of advertising appeals and Slovak cultural dimensions. Conclusions The preset contribution shows the importance of studying cultural aspects of advertising and applying findings to the field of advertising. Some limitations of the study are stated and recommendations for further research are added at the end of the article.
\end{abstract}

Keywords: global marketing and advertising, culture, values, culturally congruent advertising, advertising appeals.

JEL Classification: M15, M21

(see on website http://www.aeaweb.org/journal/jel class system.html) 


\section{Introduction}

The issue of creating advertising that is culturally congruent has been considered to be very significant to professionals in field in the past years. Culture as an important internal factor of customer behavior cannot be ignored if the advertising campaigns aim to address its target audience effectively. Values, the core of culture, are learned through the process of socialization at an early age and during the subsequent years they are relatively stable and difficult to change (Hall 1989). Moreover, based on values system we can differentiate the members of one culture from another (Hofstede 2001). Although the world is in recent decades getting a "global village", and therefore some sort of convergence in human behavior is expected, the trend of convergence of consumer behavior has not been scientifically proven. Moreover, the existence of a group of people across borders, who have homogeneous values, needs and requirements is highly questioned (De Mooij 2004). Some authors dedicated to issue admit that the needs of the population as a whole may be getting universal, but attitudes, motivations and manifestations of need of particular consumer vary on a large scale (De Mooij 2010). If needs and values of consumers differ from culture to culture and the existence of global community is in doubt, than the effectiveness of global, i.e. standardized approach in global marketing and advertising is also questionable and should be reconsidered.

Along this argument we agree with the statement that the basic debate in global marketing and advertising should not only be about the efficiency of standardization but about the effectiveness of cultural segmentation. In fact, more profound knowledge and understanding of cultural specificities of each country are getting to the forefront of today.

The aim of this article is to contribute to existing knowledge in the area of cultural congruent advertising. Present research points at some existing general rules in Slovak advertising style by analyzing the preferences and frequency of usage of advertising appeals in Slovak television advertising. The exploration of the coherence between the Slovak cultural dimensions and the preferred usage of advertising appeals confirms the integral role culture plays in advertising. The main contribution on the practical level is the formulation of recommendations for the advertising practice in the process of creating advertising campaigns that are culturally congruent with the Slovak values.

\section{Cultural aspects of advertising}

De Mooij (2010) argues that advertising is a symbolic artifact made on an agreement basis within a certain culture. Sender creates a message for a recipient in order to reflect his possible response, whilst the sender uses shared knowledge based on their common culture. The recipient uses the same set of cultural knowledge to decrypt messages, and then he evaluates the content of the message and finally formulates a response. Therefore, it is the cultural knowledge that provides one of the bases for understanding the interactions within the communication model. If an ad crosses the boundaries between cultures where shared conventions are missing, a misunderstanding between the sender and the recipient of the message may occur. Content, form and style of ads are reflections of communication style at interpersonal level. At the same time, however, they reflect the various tasks that advertising performs in different cultures.

Svetlik (2003, p. 174) confirms the strong link between the culture and advertising by his quote "advertising is a reflection of culture of a country." We can see some differences in the advertising style of each country, stemming from existing cross-cultural differences. The preference of a selected advertising style, appeal or implementation of advertising in a particular country allows us to do the same generalization, based on which we define so called national advertising styles. Concerning the issue of cultural congruent advertisement in a global perspective, we can for example distinguish among the American, German or British style of advertising (Svetlik et al. 2008).

\section{National advertising styles}

English advertising style reflects the individualistic and masculine society. Therefore, it is preferred to show one person or couple in the commercial rather than large group of people. Advertising appeals that highlight status, prestige but also appeals to the personality and personal success are fre- 
quently used. Common is the use of celebrities in advertising, but also comparative type of advertising. Reflection of prevailed masculinity in the society is expressed in strong differentiation of roles between the sexes. Lower expression of respect for authority is often used by portraying the image of young people. Young people have the same status as the elderly, in fact they often advise the elders. Advertising reflects the existing class differences. For the lower middle class is advertising directed mainly to inform about the advantages of purchase of the product in terms of low prices and at the same time reflecting the normal standard of quality. A higher social class is addressed by advertising, which emphasizes the image of the product and reflects fashion trends. Characteristic of English advertising is the use of direct explicit communication, use of persuasive techniques and arguments. Among the preferred advertising formats are lecture presentation that uses the advertised product recommendation and testimonial by known people or celebrities. Often is also used humor and parody (Svetlik 2003).

American advertising style is largely similar to the English style of advertising. It also reflects the individualistic and masculine culture. The preferences of usage of advertising appeals reflect American culture. There is a strong emphasis on appeals that manifest assertiveness and are expressed in direct, explicit communication with stress on competitiveness. Often, the personification of the main message is used for direct addressing of consumer. In advertising is characteristic an exaggeration. The preferred advertising format is a lecture using arguments based on the specific facts and figures with explicit conclusions to the recipient why he or she should buy the product being advertised. Popular is the use of celebrities who recommend the product on the basis of their own usage. Favorite is the comparative advertising, which allows the recipient to decide "voluntarily" and choose the better product in between (Svetlik 2003).

German advertising style is based on a clear structure and appropriate use of explicit language needed to reduce existing uncertainty. Apparent is the existence of a strong orientation of advertising on using information, data and facts. Favorite advertising formats include lessons, testimonial and direct demonstration including display of how the product is used and other additional information. Germans prefer to have the presentation of the product in logical continuity. Desired appeals are quality, technology and design. The contribution of the product and its technical details are clearly demonstrated, preferably in the form of statements of experts or independent audit associations. Also among important appeals belong tradition and history, which are associated with the high quality of the product. It is common that the quality of the product is often more important than its price. Nevertheless, an emphasis is also placed on cleanliness and order (Svetlik 2003).

French advertising style reflects the connection between individualism and respect for authority. This means that people want on the one hand to do things by themselves and stand out, on the other hand feel some dependency on other people. Typical features of French advertising are bizarre, fantasy and efficient element. In TV commercials is often used drama, less frequent is the orientation on the product. Prevailing is a strong focus on enjoyment and pleasure as well as emotions presented in the form of a story. In ads typically prevails symbolism with relatively little text. Favorite appeals are beauty, sensuality and eroticism. Beautiful women are shown as a metaphor for aesthetics, image and style (Svetlik 2003).

Based on the introduction of the advertising styles mentioned above, is it possible to define as well a Slovak advertising style? If we are assuming that the answer is yes, in what will it be different from other styles of advertising in the world? What advertising appeals will be the most used as a part of the creative advertising strategy in term of selection and frequency of usage based on the differences reflecting Slovak cultural values? 


\section{Advertising appeal as a part of the creative advertising strategy}

The general conclusion from the study of the theory of advertising models is the recognition that an essential condition for the creation of a successful and an effective advertising is a good advertising strategy, which consists of marketing and creative strategies (Svetlik 2012). For the purpose of attaining the objectives of this paper we will not focus on the marketing strategy, but only on the creative advertising strategy, namely on its one important part - the advertising appeal.

The main objective of advertising appeal is to attract the attention of a target group to promote products or messages. Nowadays the prevailing trend is a strong saturation of advertising. Ads attack consumers at almost every step. Appropriate selection of attractive advertising appeal within the overall creative advertising strategy therefore becomes a very important aspect in generating interest among the target group. Advertising appeal is characterized as the content of the message that appeals to a specific characteristic of the product. This characteristic of a product should be, from the perspective of a potential customer, engaging or interesting, and may either appeal to the emotions or to rational thinking. It expresses the hidden basic values of the target group and thus its motivation. Advertising appeal should emphasize in what the product is better product from its competition (Světlík In: Kloudova 2010). In addition, selected appeal should be also reliable. As experts point out, this requirement is the most difficult one, because many customers have doubts about the credibility of advertising as such (Labska, Tajtakova, Foret 2009).

De Pelsmacker divides advertising appeals into emotional (joy, fear, etc...) and rational ones (quality, performance, etc.) (De Pelsmacker et al 2007). Kotler adds another group - moral appeals. They are trying to appeal to moral values such as helping others, environmental protection and so on (Kotler, Armstrong 2004).

What is, however, important to note is that the aim of ads creators is to combine the advertising appeal with the promoted product so it creates positive associations in the minds of consumers. As a result, according to Dahl, an effective ad is the one that appeals to the positive values of the target group. Otherwise, the target group would not be able to identify itself with the product and it would drift apart from it (Dahl 2002). In other words, advertising would fail completely in meeting its target to get the consumer interested and to persuade him.

The question remains therefore, which appeals are effective and positively perceived by consumers. On the basis of an argument that the values are the source of appeal (Dahl, 2002) and at the same time the core of culture (Hofstede 2001), we would argue that advertising appeals, which have the potential to effectively reach the target audience, will be based on its cultural values (Ihnatova 2013). In this context we are talking about culturally congruent advertising appeals.

Research done in this area confirms to some extend existing differences in the usage of appeals across culture. In fact, majority of the findings suggest that there is systematic variation of preferences in usage of appeals across culture (Dahl 2004).

The present article focuses on the analysis of preferences and the frequency of usage of individual advertising appeals in Slovak TV ads, in selected product categories. For the subsequent explication of findings in context of cultural aspects of advertising, we use the Hofstede model.

\section{Hofstede model}

In the present paper we are going to be able to meet the outlined goals based on a psychological research in the intercultural field. This type of research does not seek only the description of existing differences and similarities in advertising, but also seeks to identify a degree of prediction of the observed differences. Finally, there is an opportunity to compare results with already existing findings of other countries. Most of the cross-cultural psychological research conducted in the past was supported by the work of Geert Hofstede (Dahl 2004).

Despite existing criticism of Hofstede model (questioned representativeness of sample, estimation results of certain countries, etc.), this model will serve as a theoretical base for the explication of individual choice preferences identified in advertising appeals displayed in examined commercials from the perspective of the Slovak cultural values. 


\section{Brief introduction of the Hofstede model}

Geert Hofstede, the Dutch researcher, while working for the large multinational organization IBM realized that even though the company operated under its own set of corporate culture, the cultural differences on the individual level have also highly influenced the work of its employees. Therefore, he started to explore existing differences in thinking and social action among company's members. To collect the data he used the paper-and-pencil survey among IBM employees in more than 70 countries asking also many questions about their values. The survey was conducted for the first time in 1968 and then repeated in 1972 with the final amount of 116,000 questionnaires covering 50 countries worldwide and 3 regions. Later in 2001 editions to his work had been done. With the final number of 74 countries and regions, replications as well as extensions of his IBM study included also different international populations. These studies have validated his earlier results by adding to his research samples of commercial airline pilots and students in 23 countries, civil service managers in 14 countries "upper market" consumers in 15 countries and "elites" in 19 countries. Hofstede has introduced based on the results of his research a model that identifies four primary dimensions that help to understand the intercultural differences: Power Distance (PDI), Uncertainty Avoidance (UAI), Individualism (IDV) and Masculinity (MAS). Later Hofstede added a fifth dimension to his model and called it a Long-term Orientation (LTO). This Dimension was introduced after the research done in Asia and is based on Confusian dynamism. The model provides a scale from 0 to 100 for each of the five dimensions. Each country has a position somewhere between the scale, relative to other countries. These five dimensions have been empirically verified, are statistically independent and arise in all possible combinations. They reflect basic problems of any society that need to be managed although the way of coping differs. Hofstede model has been used and cited widely since its introduction by the international scholars and practitioners (Wang, Shi 2011)

\section{Applications}

The Hofstede model has the strength in its predicting power and thus is suggested to be used in the area of predicting behavior (De Mooij 2004). Also, the model has been used to clarify the intercultural differences if the field of the concept of self, personality and identity. All of this in turn helps to explain the variations in branding strategy in global marketing (De Mooij, Hofstede 2010). The model serves as a base for explaining the area of information processing, such as differences in perception and categorization which in turn influence interpersonal and mass communication as well as how advertising works (De Mooij 2004). To summarize, when marketing managers need to make an approximate about cultural differences between the company's home market and the foreign market, this model is used the most. It helps to segment the world on a country level and allows adapting similar strategies in a country segment (De Mooij 2004).

\section{Critique}

Firstly, many questions in the survey were asked about work related behavior and preferences that can be truly answered only by people who are familiar with the relevant work situation (De Mooij 2004). Secondly, Hofstede did not measure feminine scores directly. In fact, while measuring the MAS index he considers the lack of masculinity directly to be feminine, which does not need to be always true (Wang, Shi 2011). Thirdly, results for some countries have not been measured directly. For example the data for China has been only estimated. Hofstede derived its results from other Asian countries, Taiwan and Hong Kong (Wang, Shi 2011). Finally, the composition of Hofstede model sample has been widely criticized in the past.

In our contribution we draw on Hofstede's cultural dimension measured by research conducted under the grant project led by Jaroslav Svetlik in Slovak Republic (Svetlik et al., 2008). Svetlik and his team used the original questionnaire by Hofstede VSM 94 (Value Survey Module). We consider it a more objective research than the original one done in 2003 by Kolman (Kolman, 2003), especially, 
in terms of representativeness of the sample. Results of the Slovak cultural dimension are presented in Table 1. These results will be used for explication identified preferred advertising appeal in Slovak television advertising.

Table 1 Hofstede's cultural dimensions in Slovakia

\begin{tabular}{||l|c||}
\hline \multicolumn{1}{|c|}{ Cultural dimension } & Slovakia \\
\hline Power distance (PDI) & 41 \\
\hline Uncertainty avoidance (UAI) & 89 \\
\hline Individualism/collectivism (IDV) & 70 \\
\hline Masculinity/feminity (MAS) & 28 \\
\hline Long/short term orientation (LTO) & 53 \\
\hline
\end{tabular}

Source: Svetlik, J. et al.: Cultural aspects of Czech and European advertising, 2008, p. 47.

\section{Methodology}

Main scientific method of the present research was content analysis. More specifically, we used the conceptual content analysis (Dvorakova 2010), because we examined the existence and the frequency of predefined characters (frequency of use of the advertising appeal) The conceptual content analysis was conducted on TV commercials broadcasted on the Slovak television market. TV ads were divided according to the selected product categories: beer, financial services, periodicals and nonalcoholic beverages. Analyzed ads were broadcasted on the Slovak TVs during 2012. From the initial list of all broadcasted spots within a specified timeframe, which TNS Slovakia (research agency) provided us, we selected only local campaign prepared primarily for the Slovak market. The process of selection was difficult due to the large number of broadcasted ads (in total 1,960 commercials). Overall, we identified 133 local commercials with most frequently represented segment of financial services. Table 2 shows the various product categories, the number of ads and corresponding percentages.

Table 2 Figures of commercials in selected segments

\begin{tabular}{||l|c|c||}
\hline \multicolumn{1}{|c|}{ Segments } & $\begin{array}{c}\text { Number of } \\
\text { commercials }\end{array}$ & Percentage \\
\hline Beer advertising & 23 & $17,3 \%$ \\
\hline Financial services & 75 & $56,4 \%$ \\
\hline Periodicals & 22 & $16,5 \%$ \\
\hline Non-alcoholic beverages & 13 & $9,8 \%$ \\
\hline
\end{tabular}

Source: Ihnatova, Z.: The critical analysis of creative strategies as a part of the theories of advertising. Dissertation thesis, 2013, p. 60.

To meet the objectives of the research, for the coding we selected a list of advertising appeals according to Pollay model completed with the models of Cheng and Schweitzer. Based on a detailed elaboration of manual coding, which contained a list of coding categories with a detailed description, we have trained three independent coders (the fourth coder is the author of the article). One coder is a $\mathrm{PhD}$ student at the Faculty of Mass Media of Pan European University; two others work as consultants 
in the advertising industry. The table 2 contains a complete list of advertising appeals and their description.

Table 2 Advertising appeals according to Pollaye and Cheng \& Schweitzer

\begin{tabular}{|c|c|}
\hline $\begin{array}{l}\text { ADVERTISING } \\
\text { APPEAL }\end{array}$ & APPEAL'S DECSRIPTION \\
\hline 1. Effective & appropriate, useful, functional, comfortable (clothes), strong, tasty \\
\hline 2. Good & $\begin{array}{l}\text { long-lasting, permanent, persistent, tenacious, winner of awards for } \\
\text { quality }\end{array}$ \\
\hline 3. Suitable & handy to hand, saving time, practical, multi-use, user-friendly \\
\hline 4. Beautiful & $\begin{array}{l}\text { beautiful, elegant, modern, fashionable, attractive, increasing the at- } \\
\text { tractiveness of the buyer }\end{array}$ \\
\hline 5. Economical & economic, bargain, discount, saving costs \\
\hline 6. Luxury & rich, valuable, elegant, luxurious \\
\hline 7. Singular & rare, unusual, exclusive, tasty, hand-processed, unique product \\
\hline 8. Popular & $\begin{array}{l}\text { known, regular, universal, everyday, the highest sales, commonly } \\
\text { known }\end{array}$ \\
\hline 9. Traditional & classic, historic, legendary, traditional production, measured over time \\
\hline 10. Modern & $\begin{array}{l}\text { current, new, progressive, progressive, scientific, one step ahead of } \\
\text { others }\end{array}$ \\
\hline 11. Natural & organic, nutrition, natural, organic, harmony between man and nature \\
\hline 12. Clever & $\begin{array}{l}\text { knowledgeable, educated, intelligent, experience and expertise in eval- } \\
\text { uating the product }\end{array}$ \\
\hline 13. Magical & miraculous, magical, mysterious, mythical, amazing, surprising \\
\hline 14. Productive & ambitious, successful, proficient, skilled, accomplished \\
\hline 15. Relaxation & $\begin{array}{l}\text { relaxation, tranquility, calm, party, product brings comfort and relaxa- } \\
\text { tion }\end{array}$ \\
\hline 16. Mature & mature, older, mature, respectful of elders, the product is rated Elderly \\
\hline 17. Young & children, teens, junior, teenager, rejuvenating nature of the product \\
\hline 18. Safety & $\begin{array}{l}\text { sure, stable, the possibility of exchanging and returning, secure, confi- } \\
\text { dent }\end{array}$ \\
\hline 19. Morality & human, fair, honest, ethical, honorable \\
\hline 20. Humble & patient, humble, innocent, shy, sensitive \\
\hline 21. Adventurous & bold, brave, having courage \\
\hline 22. Sex & erotic, romantic, lustful, amorous \\
\hline 23. Independence & $\begin{array}{l}\text { autonomous, independent, non-conformist, free, spontaneous, do it } \\
\text { yourself }\end{array}$ \\
\hline 24. Status & jealous, prestigious, dominant, competitive, rich \\
\hline 25. Affiliation & $\begin{array}{l}\text { social, friendly, sociable, popular by other people, reciprocity, confor- } \\
\text { mal }\end{array}$ \\
\hline 26. Care & charity, caring, loving, helping, worthy of gratitude \\
\hline 27. Family & kinship, marriage, privacy and home, marriage, kinship and affinity \\
\hline 28. Patriotisms & national, patriotic, identity, civil society \\
\hline
\end{tabular}




\begin{tabular}{|c|c|}
\hline 29. Health & energetic, healthy, strong, stamina, vigor, vitality \\
\hline 30. Cleanness & schedules, clear, precise, smelling, spotless \\
\hline
\end{tabular}

\section{Results}

The largest representation in analyzed television commercials in all examined segments has the appeal to relaxation (product brings relax, rest, quietness, etc.), followed by the appeal of suitable (time-saving, practical, multi-use, user-friendly), then the appeal of saving (economic, good bargain, discount, saving costs ), the appeal to patriotism (national, identity), the appeal of natural (organic, ecologic, harmony between nature and man) and the appeal to affiliation (social, friendly, sociable, popular among people). Graph 1 shows the results with corresponding percentage.

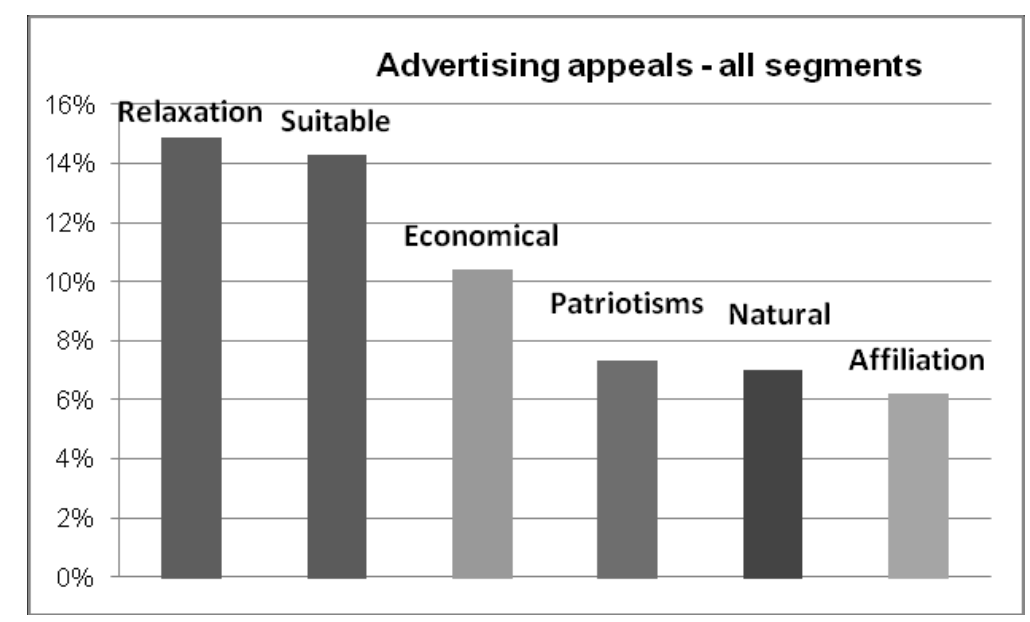

Source: Ihnatova, Z.: The critical analysis of creative strategies as a part of the theories of advertising. Dissertation thesis, 2013, p. 65.

\section{Graph 1 Frequency of usage of advertising appeals in all examined segments}

In the surveyed segments the preferences of individual advertising appeals are somehow different and reflect existing influence of product category on creative strategy. The most used appeal in TV commercials for beer is invoking patriotism (17.2\%), followed by appeals to affiliation (14.6\%), of traditional (13.2\%) and to relaxation (11.9\%). In the financial services segment the most widely used appeal is to saving (24.4\%), followed by the appeals appropriate (12.1\%), efficient (10.3\%) and to family $(7.5 \%)$. Concerning the periodicals segment, in the examined TV commercials the largest proportion of appeal is appropriate (21.4\%), then appeals of high quality (10.2\%) and modern (10.2\%), followed by the appeal luxurious $(9.2 \%)$ and popular (8.2\%). In the last examined segment, non-alcoholic bevarages, the most frequent appeal is to relaxation (23.0\%), then natural $(16.4 \%)$, beautiful $(13.1 \%)$ and to health $(11.5 \%)$.

\section{Interpretation of results}

Taking into account the existing Slovak cultural values, we can interpret the findings as follows: Slovaks, in order to reduce unconscious uncertainty as a result of higher Uncertainty Avoidance Index (UAI: 89), need to be exposed to appeals, which are primarily focused on rational arguments 
that offer clear and logical benefits of the product. Our research shows that the most commonly used rational appeals include such appeals as suitable (handy, time-saving, practical) and economic (saving, good bargain), which meet these conditions. The appeals to relaxation is on the contrary an appeal, which operates mainly on the emotional level, but basically has a similar function - to reduce uncertainty in the sub consciousness by emphasizing that the product brings peace and rest, which is the opposite of uncertainty and nervousness. Relaxation is the appeal recommended for countries with predominant feminine values, i.e. for Slovakia as well (MAS: 28).

In the investigated spots the predicted appeals emphasizing the prevailing higher Index of Individualism in society were not confirmed (IDV: 70). Appeals invoking distinction, freedom, independence, personal achievement, individual benefits and preferences, i.e. appeals to autonomy, status and to productiveness were not often presented in the examined spots. We could partially explain this fact by the prevailing feminine values of Slovaks and their reflection in advertising. Appeals based on a low Masculinity Index are in a relatively strong contrast with appeals emphasizing a higher Index of Individualism.

Based on results from our research, we would like to present these recommendations for the ad practice in developing culturally congruent television advertising: when choosing an advertising appeal, to prefer the emotional appeal to relaxation (product brings peace, tranquility, rest) and from rational appeals suitable (handy, time-saving, practical) and economic (saving, good bargain). Overall, we recommend to give a greater priority to appeals focused on the pragmatic component of perception, because Slovaks are more responsive to logical arguments than to exaggerated emotional appeals. Exaggeration based on emotional sensations is perceived more negatively and in combination with the overall general rather reserved to negative perceptions of advertising it can have a negative advertising effect on a recipient. Neverthless, the specifications based on the product category need to be taken into account as well.

\section{Benefits and limitations to research}

The present article has brought new insights on the issue of cultural congruent ads for the Slovak advertising market in theoretical and practical domains. The benefits of the paper can be divided into three basic categories:

- contribution to further studies addressing the issue of culturally congruent advertising in the context of the Slovak culture,

- contribution to the teaching of subjects dedicated to marketing and marketing communications,

- contribution to advertising practice in selecting advertising appeals that are culturally congruent.

In the presented research, we have examined the TV commercials only in selected segments (beer, soft drinks, periodicals and financial services). Based on our experience from research execution we would recommend to include further segments which would be able to generate relevant data and thus to contribute to solving the issue. The segment of mobile operators seems to be very interesting. All three companies (Orange, Telecom, and O2) belonged to the 10 largest advertisers in Slovakia in 2012 (strategie.hnonline.sk). Moreover, most of the aired commercials were local campaigns.

We realize that examined four segments are not a representative sample, and thus served only partial in the analysis and selection frequency of use of individual advertising appeals. A larger number of segments surveyed would ensure greater representativeness of the present research.

Also, it is important to mention the fact that although we have investigated one of the most important means of disseminating advertising message - television, we need to take into account that also other media such as internet, print, radio and outdoor advertising have their own important role in 
the media mix. Their specifications are reflected in creating advertising campaigns and therefore, some differences in selection of advertising appeals are expected.

For further research in selected issue, we would recommend to use the GLOBE model (Hoppe 2007). The potential of this intercultural model in application to the field of marketing and advertising appears to us as a better option in solving culturally congruent research problems. Unfortunately, the dates for Slovak Republic are not available up to this date.

\section{Conclusion}

Cultural aspects of advertising are gaining interest of the theorists and practitioners in the field. Culture as in integral factor of consumer behavior influence greatly the decision making process. Advertising that is based on the cultural values of the local target audience shows higher effectiveness than global, standardized advertising. The presented paper examined the issue of culturally congruent advertising in the context of Slovak culture.

The conceptual content analysis introduced the preferences and frequency of usage of advertising appeals - the essential part of the creative advertising strategies that have the role to drawn attention and raise interest about the product or services promoted in the ad. Interpretation of the results showed positive relationship between the findings and existing Slovak cultural dimensions. Also, findings served as a basis of creating recommendations for the advertising practice. Lastly, limitations of the study are stated and some suggestions for further research are introduced.

\section{References}

Dahl, S. (2002). Cultural values in Beer Advertising in the UK, the Netherlands and Gemany. [online]. [Cited 2013-06-30] Avaliable from Internet: 〈www.sietar.otr.uk.library.pl>.

Dahl, S. (2004). Cross-Cultural Advertising Research: What Do We Know About the Influence of Culture on Advertising? [online]. [Cited 2013-05-08] Middlesex University Discussion Paper No. 28. 2004. Avaliable from Internet: http://ssrn.com/abstract=658221

De Mooij, M. (2004). Consumer Behavior and Culture. Consequences for Global Marketing and Advertising. 2nd edition. Thousand Oaks, CA: Sage. 403 p.

De Mooij. M. (2010). Global Marketing and Advertising. Understanding Cultural Paradoxes. $3^{\text {rd }}$ edition. Thousand Oaks, CA: Sage. 323 p.

De Mooij, M., Hofstede, G. (2010). The Hofstede Model. Application to global branding and advertising research. International Journal of Advertising, 2010, 29 (1), pp. 85-110.

De Pelsmacker, P. at all. (2007). Marketingová komunikace. [Marketing Communication.]. $1^{\text {st }}$ edition. Praha: Grada Publishing. 600 p.

Dvorakova, I. (2010). Obsahová analýza. [Content analysis]. Antropowebzin, 2/2010, pp. 95-99.

Hall, E. (1989). Beyond Culture. $2^{\text {nd }}$ edition. New York : Anchor Books Editions. 298 p.

Hofstede, G. (2001). Culture's Consequences. Comparing Values, Behaviors, Institutions, and Organizations Across Nations. 2nd edition. Thousand Oaks, CA: Sage. 596 p. 
Hoppe, M. (2007). Culture and Leader Effectiveness: The GLOBE study. In Central European Journal of Communication.

Kloudova, J. et al (2010). Kreativní ekonomika. Trendy, výzvy, přiležitosti. [Creative Economy. Trends, Challenges, Opportunities.]. $1^{\text {st }}$ edition. Praha: Grada Publishing. 218p.

Kolman, L. et al. (2003). Cross-cultural differences in Central Europe. Journal of Managerial Psychology. Vol. 18, no. 1, pp. 76-88.

Kotler, P., Armstrong, G. (1992). Marketing. $1^{\text {st }}$ edition. Bratislava: SPN. 385 p.

Labská, H., Tajtáková, M., Foret, M. (2009). Základy marketingovej komunikácie. [The principals of Marketing Communication.]. $1^{\text {st }}$ edition. Bratislava: Eurokódex. 232 p.

Svetlik, J. et al (2008). Kulturní aspekty české a evropské reklamy. [Cultural aspects of Czech and European advertising.]. $1^{\text {st }}$ edition. Praha: Professional Publishing. 56 p.

Svetlik, J. (2003). Marketing pro evropský trh. [Marketing for European Market.]. $1^{\text {st }}$ edition. Praha: Grada Publishing. 272 p.

Svetlik, J. (2012). O podstatě reklamy. [The essence of Advertising]. $1^{\text {st }}$ edition. Bratislava: Eurokódex. 312 p.

Ihnatova, Z. (2013). The critical analysis of creative strategies as a part of the theories of advertising. [Dissertation thesis]. Pan European University. Faculty of Mass Media. 123 p.

Wang, J., Shi, X. (2011). Interpreting Hofstede Model and GLOBE Model: Which way to go for Cross-cultural research. International Journal of Business and Management. Vol. 6, No. 4, May 2011, pp: 93- 99.

199 dní televíznej reklamy. Statégie online. [online] [Cited 2013-06-08]. Available from Internet: 〈http://strategie.hnonline.sk/spravy/media/199-dni-televiznej-reklamy>

\section{Author contact:}

Mgr. Zuzana Ihnátová

Faculty of Mass Media, Paneuropean University

Tematinska 10, 85105 Bratislava, Slovakia

Phone: +421908957 839, e-mail: zuzana.ihnatova@paneurouni.com 